\title{
PRIORITY DETERMINATION IN WATER RESOURCES ALLOCATION IN HIRMAND RIVER AREA
}

\author{
Mohammad Hussein Karim¹, Mahmood Mohammadghasemi² \\ ${ }^{1}$ Department of Resource Economics, Kharazmi University, Tehran-Iran \\ ${ }^{2}$ Department of Agricultural Economics, Sistan Agricultural and Natural Resources Research and Education \\ Center, AREEO, Iran \\ Link to this article: https://doi.org/10.11118/actaun.2021.005 \\ Received: 15. 10. 2019, Accepted: 15. 12. 2020
}

To cite this article: KARIM MOHAMMAD HUSSEIN, MOHAMMADGHASEMI MAHMOOD. 2021. Priority Determination in Water Resources Allocation in Hirmand River Area. Acta Universitatis Agriculturae et Silviculturae Mendelianae Brunensis, 69(1): 51-58.

\begin{abstract}
Supply and demand management of Hirmand water resources is one of the most important problems facing by policy makers and they will not be able to manage this sector properly without specifying the future prospects of the Hirmand Area. The main objective of the research is to determine the priority of future allocation of water resources in the Hirmand Area by using dynamic optimization models in different climatic conditions in agricultural, household, public and environmental sectors. The method of this research is based on the applied scientific method. The required statistics and information are obtained by the library method. In this research, the water demand functions in the agricultural, household, public and environmental sectors as well as the water supply function are achieved initially in different climatic conditions and then the general objective function for determining the allocation priority is estimated by using EVIEWS and GAMS soft wares. The results showed that in different conditions for agricultural sector, water demand is inversely related to water price, therefore under drought, wet and normal conditions, if the water price increases by one percent, the product will have a negative value decrease by $4.4 \%, 88 \%$ and $1.006 \%$ respectively. Moreover, since in this model the demand function for water is only a function of the price, the return to the scale is decreasing and Iso Quant Curve in the agricultural sector has a negative technical substitution rate in all aquatic conditions. In household demand, the results showed that with increase in water price, consumption decreases and rise of price is a necessary condition for reducing consumption, but is not sufficient. The average consumption based on the current trend is $12.42 \mathrm{M}^{3}$ per month for each household. The reaction in the amount of demand change versus the change in the number of stormy days is positive and equal to 0.39 . The results of the study for determination of water allocation indicate that if the next year is drought, priority of allocating for household sector will be (44\%) - agriculture (41\%) - Public (10\%) and environmental (5\%). In normal year, allocation priority will be (41\%) household - (37\%) agriculture - (14\%) environmental and public sector (8\%). While in rainy year, the allocation of priority has recorded for agriculture (43\%) domestic (39\%) - environmental (15\%) and public (7\%). At the end some strategic policies based on research findings are suggested.
\end{abstract}

Keywords: Sistan, dynamic, optimization model, social welfare, priority determination

\section{INTRODUCTION}

By predicting the trend of water consumption from the beginning of the $20^{\text {th }}$ century to the present time and till 2050, it was found that on the global scale, the cross point of consumption and the amount of available water will be around 2040. This cross has occurred on a regional and national scale, but for some nations has occurred from many years 
ago and is happening to many others at the present time (Mohammad Ghasemi, 2016). According to the study related to Hirmand's water availability in different years, it is indicated that over the period of last 30 years, Hirmand has faced with 9 various drought years. The result of these consequences is that since the flow of the Hirmand River is the only source of water supply which is known as the current social-economic life, any fluctuations in the rate of its inflow affect the life of the region and the country. Although geographically is a part of Iran's plateau, Sistan is a vast area in the southeast part of Iran plateau. As Egypt's life depends on the Nile River, India on Ganga River, the life of Sistan also depends on the Hirmand River for thousands of years (Ibrahim Zadeh, 2012). According to the Zabul station statistics, during the past 40 years, the average annual rainfall rate in Zabol was about $61 \mathrm{~mm}$ that the lowest of which was in 2001, with a total of $7.2 \mathrm{~mm}$, and the highest was in 2005 with a total of $129.5 \mathrm{~mm}$ (Karim, 2012).

Therefore, considering the essential role of the Hirmand River, considering the priority of allocating future water resources in drought-wet and normal conditions is essential for the agricultural, domestic, and environmental sectors.

\section{Literature Review}

Mohammad Ghasemi et al. (2017), in the study of water management allocated in the agricultural sector by using a dynamic randomization method under conditions of uncertainty for products such as wheat, barley, melon, watermelon, grape and yoghurt showed that by considering the amount of water allocated and the percentage of water deficit in relation to the optimal allocation, cultivation of ruby grape can be the best choice among crops with the highest expected value of profit in normal, wet and dry conditions.

Zhanqi Wang (2015) in studying optimal allocation of water resources for use in agricultural, industrial, urban and hydroelectric sectors based on economic criteria in China showed an optimal model with dynamic tool that can improve economic revenue compared to other allocation models, because in this study the functions of agricultural, industrial, hydroelectric and urban sector profits were investigated by using both static and dynamic methods.

Zeng (2014) by using simulation of dynamics in systems, showed how to operationalize water resource management with an interconnected approach. In this research, by using a dynamic approach to systems and paying attention to the concept of use in agricultural, industrial, urban and environmental sectors, a methodology for identifying problems has been developed.

Ahmed et al. (2010) have used dynamic tools to evaluate water management policies. This study refers to the dynamic simulation in southern Florida.
This model represents an internal link between water availability and competition for increasing water demand in urban, agricultural and environmental sectors.

\section{MATERIALS AND METHODS}

In designing a model, it should be noted that relationship between the variables within the model can exist in two ways. Whether these relations are linear or nonlinear, this can be the case in mathematical planning and mathematical relations which are divided into linear and nonlinear types. Therefore, it seems necessary and essential to recognize the relationship between the system variables in order to design a model proportional to the relationships within the model. In this regard, before designing a nonlinear model, it should be shown that the relationships between the variables of the allocation system are non-linear, because most consumer goods are not complete substitutes. As a result, the utility function and consequently the demand function are nonlinear. Therefore, the objective function used in the water resource allocation model is nonlinear, because the target function considered for water resources allocation is the total surface area under the reverse curves of supply and demand for water or the total amount of consumer and producer welfare (Mohammadghasemi, 2016).

The net benefit function or the welfare function can be written as follows which should be maximized according to some constraints

$M A X N B=$

$=\sum_{J} \sum_{U}\left[\int_{L L}^{U L} F_{J u}\left(Q_{d}\right) d Q_{d}+C P_{J u} Q d \min \right]-\left[\sum_{J} \sum_{u} \int_{0}^{U L} s_{J u}(Q) d Q\right]$.

In this relation: $J$ and $u$ and counters for active areas, are the type of water use and the type of purified water, $F_{J u}\left(Q_{d}\right)$ is the inverse demand function for $Q D$ use amount in different sections.

$C P_{J u}$ is the price of silencer of demand or the held back technology price (Alternative technology), Qdminju is consuming on the $F_{J u}\left(C P_{J u}\right)$ surface, $Q d m i n=L L$ is lower limit of water consumption, $Q d_{\tau u}=U L$ is Upper limit of water consumption, $S_{J u}(Q)$ is inverse supply function for $Q s$ Reliable supply amount, and $N B=$ is the net benefits of water consumption.

The targeted objective function, which is equal to the net social interest. ie, the level below the supply and demand curve of the water, is maximized by considering a series of constraints.

\section{Extraction of the Water Demand Function in the Household Sector from the Aston-Gary Utility Function}

Based on Aston-Gary utility function,the demand function can be extracted after maximizing the 


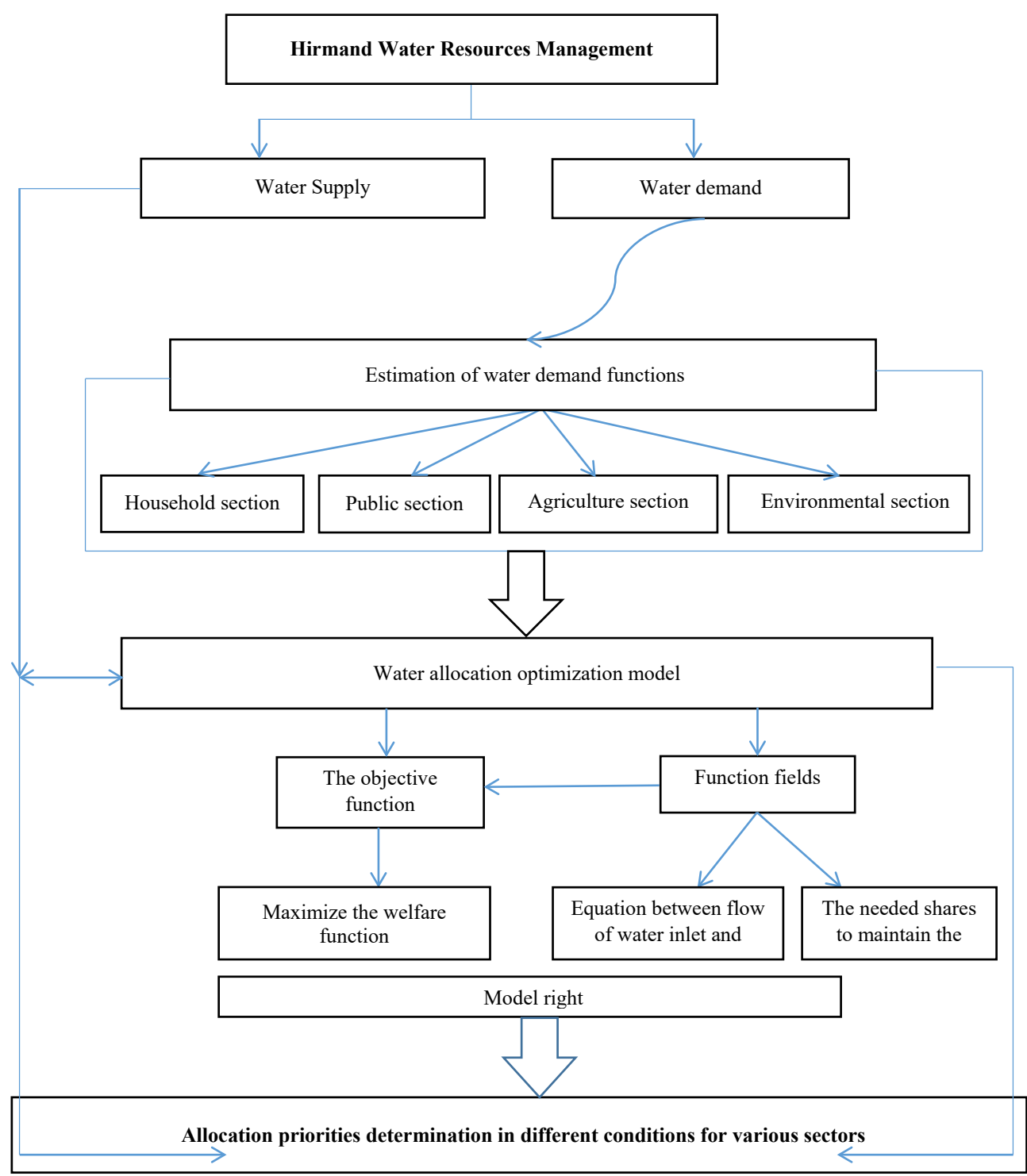

utility function relative to the budget and using the Lagrange method. In this case, the function of the mentioned request is as follows:

$Q_{w}=\theta_{0}+\theta_{1}\left(\frac{M}{P_{w}}\right)+\theta_{2}\left(\frac{P_{o t h}}{P_{w}}\right)$.

Where $Q_{w}$ is demand amount or per capita consumption of drinking water per cubic meter, $M$ is the budget or nominal household income per Rials, $P_{o t h}$ is Nominal value of other goods and services in terms of indicators. Given the assumptions of the Stone-Gary function in the demand function, $\theta_{0}$ and $\theta_{1}$ contain positive signs and $\theta_{2}$ contains negative sign. In other words, water demand shows a positive reaction to changes in income, and a negative reaction to the price of other goods and the price of water.
The demand for water in the presence of a changing climate (number of stormy days) is as follows:

$Q_{w}=\theta_{0}+\theta_{1}\left(\frac{M}{P_{w}}\right)+\theta_{2}\left(\frac{P_{o t h}}{P_{w}}\right)+\theta_{3} W+\varepsilon$.

In this relation $W$ is the number of stormy days and $\varepsilon$ is the disruptive component.

\section{Agricultural Water Demand Function}

In order to estimate the demand function of water in the agricultural sector, the profit function has been used, therefore with respect to the production function, total irrigation profit at the $j$ demand site based on water - product function is expressed as follows (Wang et al., 2006):

$$
\tilde{B}_{j}=\sum p c p_{j, c p} \times Y a_{j, c p} \times A F_{j, c p}-\sum v c_{j, c p} \times A F_{j, c p} .
$$


Where $p c p_{j, c p}$ is the product price and $v c_{j, c p}$ is the variable cost of product production. Therefore, the target function can be written as follow:

$$
\begin{aligned}
& \max \quad \tilde{\beta}_{j}, \\
& \text { s. } t: \sum_{c p} A F_{j, c p} \leq A_{j}, \\
& A F_{j, c p}^{l} \leq A F_{j, c p} \leq A F_{j, c p}^{u}, \\
& \sum_{c p} E I_{j, c p} \times A F_{j, c p} \leq Q,
\end{aligned}
$$

where $A_{j}$ is the total area under cultivating (hectare) in the area $j$ and $A F_{j, c p}^{u}$ are the upper and lower levels of cultivating area (hectare), is the amount of effective irrigation water needed during the growing season (Cubic meters/hectare) and $Q$ is total amount of irrigation water available in the $j$ area. Irrigation water demand function is estimated by using solving the model for different levels of effective irrigation water in the growing season and the corresponding shadow price and coefficients based on the Cab Douglas function $Q_{w}=\alpha P^{\beta}$. In this relation $P_{w}$ is the water price and $Q_{w}$ is volume of demanded water (Ghasemi et al., 2012):

$M V W_{j}=\frac{\Delta \pi_{j}}{\Delta Q_{j}}$,

where: $M V W_{j}$ is the final value of water (cubic meters/hectare) in area $j . \Delta \pi_{j}$ is change in profit (Rials) because of one unit change in $Q$ in area $j$ and $\Delta Q_{j}$ changes in the total amount of available effective irrigation water in area $j$.

\section{Water Supply Function}

In this research, a cost function that is a production function twin is used. The general form of cost of the water, wastewater and district water will be as follow:

$$
C=C\left(P_{k}, P_{l}, P_{M}, P_{S}\right) \text {. }
$$

Which in this relation, $C$ is total cost of production and distribution of water, $P_{k}$ the price of capital, $P_{l}$ labor price, $P_{M}$ raw material price and $P_{S}$ the price of other services.

The trans log form of the cost function can be extracted using the Taylor II series extensions as follows:

$$
\operatorname{Lnc}=\ln \alpha_{0}+\sum_{i=1}^{n} \alpha_{i} \ln p_{i}^{*}+\frac{1}{2} \sum_{i=1}^{n} \sum_{h=1}^{n} \gamma_{i h} p_{i}^{*} \ln p_{h}^{*}+
$$$$
+\sum_{i=1}^{n} \sum_{k=1}^{m} \delta_{i k}+\sum_{k=1}^{m} \beta_{k} \ln z_{k}+\frac{1}{2} \sum_{k=1}^{m} \sum_{j=1}^{m} \varphi_{k j} \ln z_{k} \ln z_{i}
$$

$i=h=1,2, \ldots, k=j=1,2, \ldots, m$.

The equation of cost function is estimated simultaneously with the contribution of equations. Because for the first reason the share of equations has the same parameters, and for the second reason the equation of share is obtained from the equation of cost and may their disruptive components have relation with each one. So it's better to estimate them with each other.

\section{RESULTS AND DISCUSSION}

Sistan plain geologically is an alluviallow sloping plain. Its lowest point is the Goodarzeh pond with 470 meters height above the sea level. The average rainfall is $58 \mathrm{~mm}$ annually and the evaporation rate of the area is about $475 \mathrm{~mm}$. The area has a dry climate and the average annual temperature in Zabul is about 21.83 degrees. The most significant result of 120-day windfall is the escalation of water from the surface of wetlands and fields and this can be stated as one of the main causes of drought occurrence in these areas. From the total lands under cultivation in Iranian plateau (12 million hectares), 196021 hectares (1.59\%) is located in Sistan and Baluchistan province and from this amount about $52.4 \%$ is in the Sistan area.

\section{Water Resources}

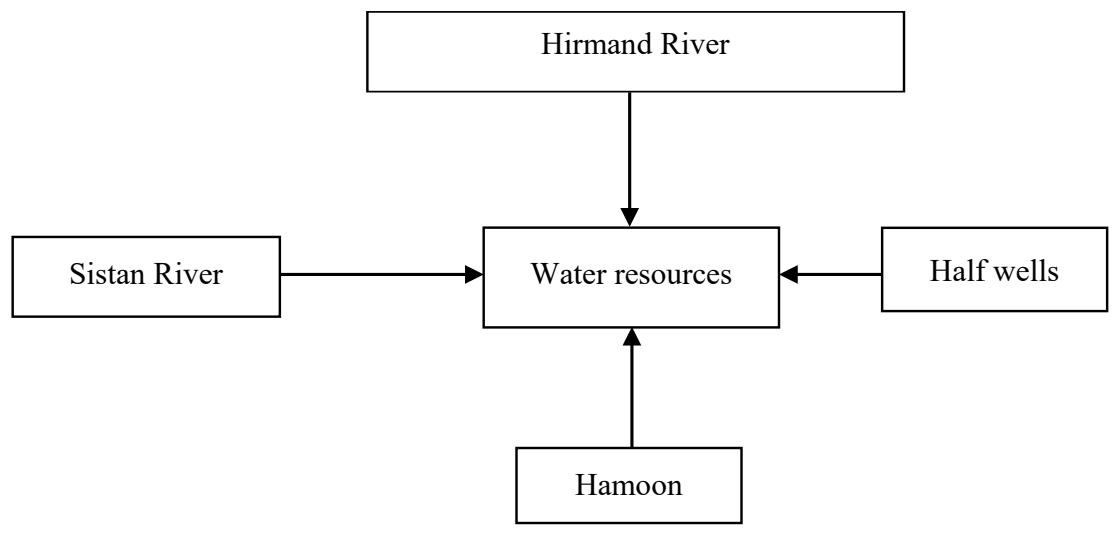




\section{Estimation of Demand for Agricultural Sector in Drought Conditions}

The water demand function of the agricultural sector in the drought situation is as follow.

$\ln Q=67.2-1.29 \ln p$

$t:(31.11)$

$R^{2}=0.58$

$D W=1.87$

$\mathrm{F}=356$

As the estimate results show, water demand has an inverse relation with the price of water. If the price of agricultural water increase, the demand for water in the agricultural sector will decrease.

\section{Demand Function of Agricultural Sector Under Normal Conditions}

Relationship (10) shows the water demand function of the agricultural sector in normal conditions.

$\ln Q=45.23-0.88 \ln p$

$t:(24.14)$

$R^{2}=0.64$

$D W=2.39$

$\mathrm{F}=236$

As the estimate results show an inverse relation with the price of water for water demand, if the price of agricultural water increase, the demand for water in the agricultural sector will decrease.

\section{The Demand Function of the Agricultural Sector in Wet and Rainy Conditions}

Relationship (11) shows the demand function of water in the agricultural sector under tropical wet and full of rain conditions.

$\ln Q=23.2-1.05 \ln p$

$t:(10.17)$

$R^{2}=0.80$

$D W=1.74$

$\mathrm{F}=259$

As the estimate results show, water demand has an inverse relation with the price of water. If the price of agricultural water increase, the demand for water in the agricultural sector will decrease.

\section{Estimate of Household Demand Function}

Based on the above chart, in the 2009, prior to the targeting of subsidies, the consumption of every person per capita was $2.45 \mathrm{M}^{3}$ per month which by the implementation of targeted subsidies in 2011 and the realization of prices, per capita consumption decreased by $4.40 \mathrm{M}^{3}$ per month. In 2009, per capita consumption reached $8.41 \mathrm{M}^{3}$ per person. In 2010, with the implementation of the second phase of targeting subsidies and rise of prices, per capita consumption decreased to 4.37 cubic meters. In 2013, per capita consumption reached $2.42 \mathrm{M}^{3}$ per month. These statistics indicate clearly that rising in prices only could affect water consumption in a short time and people become accustomed to higher prices and they get used to the price grow again. Increasing prices seems to be a necessary condition for reducing consumption, but not an enough condition.

\section{The Number of Stormy Days}

From the average number of stormy days, different months were used for each year during the study period for the Sistan region which these data is available in the weather stations of the region and Sistan and Baluchistan province and the average number of monthly stormy days was calculated each year. Fig. 2 shows the average variation in the number of stormy days during the study period.

\section{Model Estimation}

The average consumption is obtained based on the current trend which is 42.12 cubic meters per month for each household. If on average five people are considered as a family, the average daily consumption of each household is 280.08 liters. The reaction to change in the amount of demand versus change in the number of stormy days is 0.39 , suggesting that one stormy day would increase water demand by more than 39 percent and the rise effect of a stormy day on demands is positive.

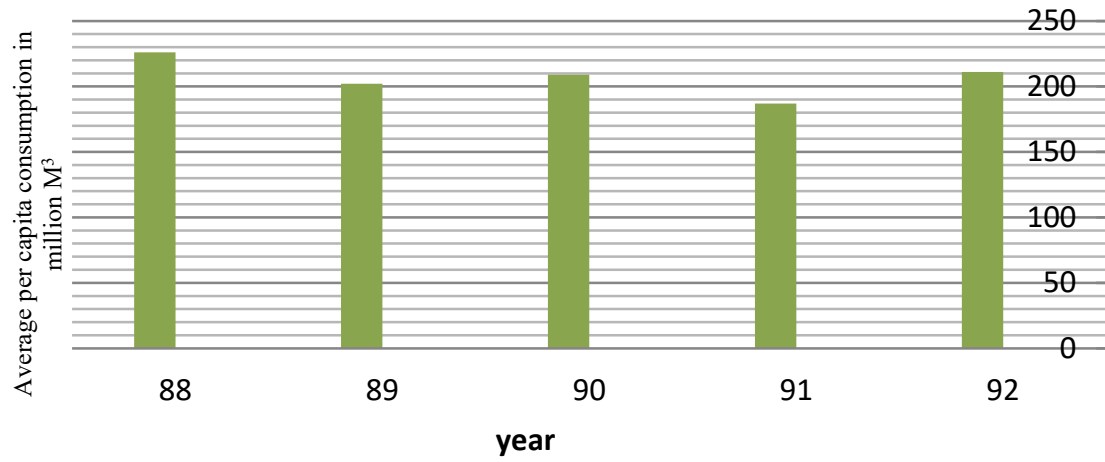

1: The trend of average changes in per capita consumption of water in Sistan region during 2009-2013 


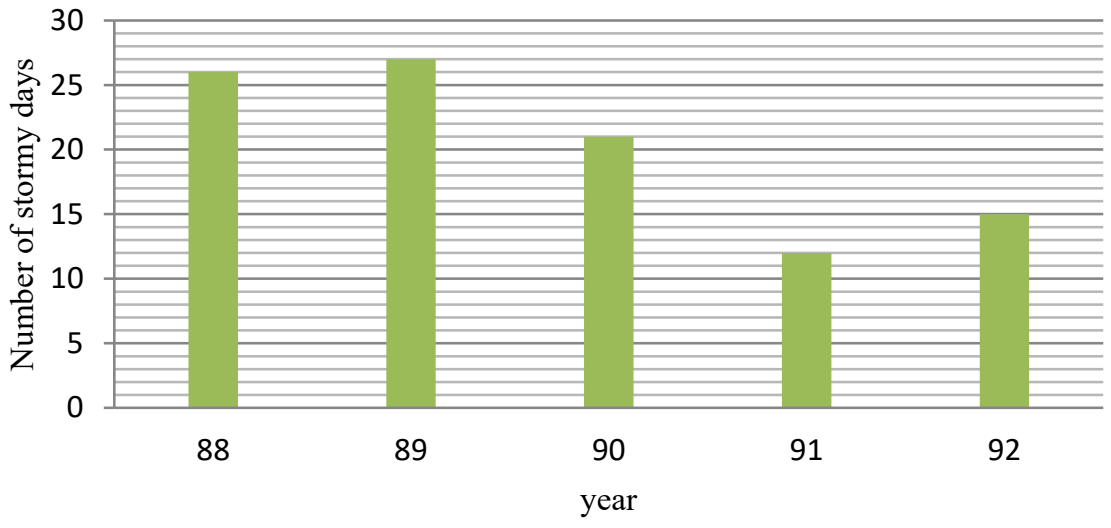

2: Changes in the number of stormy days

I: Estimation of the coefficients of the model of household demand functions

\begin{tabular}{|c|c|c|c|c|c|c|c|c|}
\hline \multirow{2}{*}{$\frac{\text { Type of demand }}{\text { Total }}$} & \multirow{2}{*}{$\frac{\theta_{0}}{12.42}$} & \multicolumn{2}{|c|}{$I n c_{i t}$} & \multicolumn{2}{|c|}{ Price $_{i t}$} & \multicolumn{2}{|c|}{$W$} & \multirow{2}{*}{$R^{2}$} \\
\hline & & Coefficient & Statistics $t$ & Coefficient & Statistics $t$ & Coefficient & Statistics $t$ & \\
\hline $\begin{array}{l}\text { Consumption classes } \\
\text { less than } 15\end{array}$ & 35.37 & 0/0025 & 9.12 & -5.72 & -7.16 & 0.37 & 63.12 & 0.83 \\
\hline $\begin{array}{l}\text { Consumption classes } \\
\text { less than } 20-15\end{array}$ & 42.01 & 0.0056 & 45.11 & -25.12 & -56.18 & 0.12 & 32.18 & 0.80 \\
\hline $\begin{array}{l}\text { Consumption classes } \\
\text { less than } 20-25\end{array}$ & 23.51 & 0.011 & 23.14 & -37.16 & -03.25 & 0.13 & 52.21 & 0.81 \\
\hline $\begin{array}{l}\text { Consumption classes } \\
\text { less than } 25-30\end{array}$ & 89.57 & 0.10 & 21.15 & -8.19 & -6.13 & 0.16 & 14.25 & 0.84 \\
\hline $\begin{array}{l}\text { Consumption classes } \\
\text { more than } 30\end{array}$ & 34062 & 0.09 & 25.17 & -5.21 & -4.75 & 0.18 & 17.26 & 0.88 \\
\hline
\end{tabular}

Source: Investigator calculations

\section{Water Supply Function}

By using the high cost function and deducting it from the total income, profit function is obtained, where the profit is also normalized (total revenue minus the total cost of the variable entity, divided by product price). By using Translog profit function derivation and also using the Lemh Hatling, the functions of the shareholder inputs can be derived from the variable of profit and the product/profit ratio.

$S_{V}=2.529+0.84 \ln p_{l}+1.48 \ln p_{k}+0.68 \ln p_{s}+1.01 \ln p_{m}$.

This function represents the long-term economic supply function of the Hirmand basin/Area in the Sistan region. The price elasticity of the long-term supply of water decreases with rising reliable water prices and this means that as much as it gets close to reliable resources and with rise in price, little can be added to reliable water supply.

Estimation and Analysis of the Economic Allocation of Water Resources in Hirmand Area in Sistan and Baluchistan Province

In this study, meteorological data was first evaluated for 30 year period by SPI index for drought, wet and normal conditions. After determining the type of year, information for 5 years of drought, wet and normal years through the equilibrium of supply with total demand for water in different price conditions and equilibrium value was obtained. This is done by writing a program in GAMS software. The equilibrium price is 4570.45 and the equilibrium amount is 2145.87 million $\mathrm{M}^{3}$. Because the equilibrium price is fixed for each consuming segment, by entering the equilibrium price in the water demand function of each section, the amount of consumption followed by the amount of welfare are obtained. Finally, using the results, information was evaluated for the next year. This is done in the next section.

The results of the estimation of the economic allocation of water resources in Hirmand area are presented in Tab. II.

Based on the above table, if the next year is drought, the priority for allocation to provide water, will be for the domestic- agricultural, public and environmental sectors respectively.

If the next year is normal, the allocation of water supply will be for the household-agriculturalenvironmental and public sectors, respectively.

If the next year is full of rain, the allocation of water supply will be for the agricultural- householdenvironmental and public sectors, respectively. 
II: Estimation of the economic allocation of water resources in the Hirmand Area using five year data in different water conditions

\begin{tabular}{|c|c|c|c|c|c|c|c|c|c|}
\hline \multirow[b]{2}{*}{$\begin{array}{l}\text { Type of water } \\
\text { usage }\end{array}$} & \multicolumn{3}{|c|}{ Drought period } & \multicolumn{3}{|c|}{ Normal period } & \multicolumn{3}{|c|}{ Period Full of rain } \\
\hline & $\begin{array}{c}\text { Amount of } \\
\text { consumption } \\
\text { Million } \mathrm{M}^{3}\end{array}$ & $\%$ & $\begin{array}{l}\text { Welfare } \\
\text { (Billions) }\end{array}$ & $\begin{array}{l}\text { Amount of } \\
\text { consumption } \\
\text { Million } \mathrm{M}^{3}\end{array}$ & $\%$ & Welfare & $\begin{array}{l}\text { Amount of } \\
\text { consumption } \\
\text { Million } \mathrm{M}^{3}\end{array}$ & $\%$ & Welfare \\
\hline Agriculture & 136 & 51 & 73419400 & 1179.9 & 47 & 82789456 & 1623 & 43 & 87123456 \\
\hline Household & 110 & 36 & 92741852 & 220 & 33 & 125789456 & 240 & 32 & 128963852 \\
\hline Public & 24 & $9 / 73$ & 45789123 & 42 & 9 & 52123456 & 58 & 12 & 60741852 \\
\hline $\begin{array}{l}\text { Environmental } \\
\text { demand }\end{array}$ & 8 & $3 / 27$ & 25874196 & 414 & 11 & 76032846 & 591 & 13 & 100584625 \\
\hline $\begin{array}{l}\text { Total net } \\
\text { welfare at } \\
\text { the basin level }\end{array}$ & \multicolumn{3}{|c|}{237896571} & \multicolumn{3}{|c|}{336735214} & \multicolumn{3}{|c|}{377413785} \\
\hline
\end{tabular}

Source: Investigator calculations

III: Estimation of the economic allocation of water resources in Hirmand Area under different water conditions of the next year

\begin{tabular}{|c|c|c|c|c|c|c|c|c|c|}
\hline \multirow[t]{2}{*}{$\begin{array}{c}\text { Type of water } \\
\text { usage }\end{array}$} & \multicolumn{3}{|c|}{ Drought period } & \multicolumn{3}{|c|}{ Normal period } & \multicolumn{3}{|c|}{ Period Full of rain } \\
\hline & $\begin{array}{l}\text { Amount of } \\
\text { consumption } \\
\text { Million } \mathrm{M}^{3}\end{array}$ & $\%$ & $\begin{array}{l}\text { Welfare } \\
\text { (Billions) }\end{array}$ & $\begin{array}{l}\text { Amount of } \\
\text { consumption } \\
\text { Million } \mathrm{M}^{3}\end{array}$ & $\%$ & Percent & $\begin{array}{l}\text { Amount of } \\
\text { consumption } \\
\text { Million } \mathrm{M}^{3}\end{array}$ & $\%$ & Welfare \\
\hline Agriculture & 120 & 44 & 65214212 & 1574 & 41 & 71459465 & 1553 & 43 & 73214219 \\
\hline household & 101 & 41 & 68251832 & 240 & 37 & 103675325 & 320 & 39 & 111962114 \\
\hline Public & 35 & 10 & 38794125 & 95 & 8 & 39144221 & 120 & 7 & 45121562 \\
\hline $\begin{array}{l}\text { Environmental } \\
\text { demand }\end{array}$ & 12 & 5 & 21624586 & 150 & 14 & 52258264 & 265 & 15 & 58126281 \\
\hline $\begin{array}{l}\text { Total net } \\
\text { welfare at the } \\
\text { basin level }\end{array}$ & \multicolumn{3}{|c|}{193884755} & \multicolumn{3}{|c|}{266537275} & \multicolumn{3}{|c|}{288424176} \\
\hline
\end{tabular}

Source: Investigator calculations

\section{CONCLUSION}

The results show that water demand has a reverse relation with water price in agricultural sector under various water conditions, if the price of agricultural water increases, the demand for water in the agricultural sector will decrease. This is consistent with previous investigations. IN addition, as in this model the demand function for water is only a function of the price, therefore the returns relative to scale is downward. Therefore, under drought, wet and normal conditions, if the price of water increases by one percent, the product amount will decrease to negative $4.4 \%, 88 \%$ and $1.006 \%$ respectively. The same production curve of the agricultural sector in all water conditions has a negative technical substitution rate. In the demand side, the estimated results show that with increasing water prices, consumption decreases, which this is consistent with previous research. In addition, the average consumption was calculated $12.42 \mathrm{M}^{3}$ per month for each household. If every household is considered as 5 members, the average daily consumption of each household will be 280.8 liters. The reaction to change of amount of demand versus change in the number of stormy days is 0.39 suggesting that one stormy day would increase water demand by more than $0.39 \%$ and the effect of a stormy day's rise on demand is positive. Modeling the determination of the allocation of water resources at the level of the Hirmand area is based on the information obtained from the estimation of the coefficients of demand functions and water supply. The coefficients of supply and demand are introduced as parameters in the model. According to the estimation of the economic allocation of water resources in Hirmand Area, it is shown that during the drought, the water requirement of the Hamoon wetland decreases in the first place, and then the water in the agricultural sector will be reduced to provide water for drinking and sanitation for urban use. If the water used in the agricultural sector remain unchanged, the net welfare will be zero at all consumptions. In the normal and wet period, the second and third scenarios, the welfare increases 
compared to the drought period. In such a way the net welfare of the entire period from the drought to the normal period and then to the wet period is increased. In addition, the tables show that the priority of consumption is based on net welfare so that household use be at the top of the list. Then the costs of the agricultural sector and the environmental sector and finally the public sector will be in the next category.

\section{Executive Suggestions}

\section{Agricultural Sector}

Sustainable water is available to the user

\section{The Household Section}

Considering too much water consumption in this section both in the whole region and in the consumer classes, it is recommended that this consumption pattern become corrected and investing be done towards religious beliefs to reduce water consumption. The risk of the economic and social benefits of providing or not providing water for the Hamoon Wetlands be investigated.

\section{Water Supply Sector}

Considering the possibilities of the country, water and sewage and regional water companies and other executive agencies use new management systems and also use them to manage water transportation systems (Like using solar energy).

\section{REFERENCES}

AHMAD, S. and PRASHAR, D. 2010. Evaluating municipal water conservation policies using a dynamic simulation Model. Water resource Management, 24(13): 3371-3395.

EBRAHIMZADE, E. and LASHKARIPOOR, G. 2012. Drought crisis in Sistan and adjust its strategies. Political and Economic, 167(15): 226-231.

GHASEMI, A., GHASEMI, M. and PESSARAKLI, M. 2012. Yield and yield components of various grain sorghum cultivars grown in an arid region. Journal of Food, Agriculture and Environment, 10(1): 455-458.

KARIM, M., GHASEMI, M., NAROUI, M. R. and KOOHKAN, S. 2012. Effects of Yaghoti grape cultivation on economy of rural families in Sistan and Baluchistan province-Iran. International Journal of Agriculture and Crop Sciences, 4(7): 386-389.

MOHAMMADGHASEMI, M. et al. 2017. Water Resources Management of Hirmand River Basin for Agricultural Productions Using Stochastic Dynamic Programming. Journal of Hydrosciences and Environment, 1(1): 20-24.

MOHAMMADGHASEMI, M. SHAHRAKI, J. and SABOHI, M. S. 2016. Optimization Model of Hirmand River Basin Water Resources in the Agricultural Sector Using Stochastic Dynamic Programming under Uncertainty Conditions. Agricultural Management and Development, 6(2): 163-171.

WANG, Z., YANG, J., DENG, X. and LAN, X. 2015. Optimal Water Resources Allocation under the Constraint of Land Use in the Heihe River Basin of China. Sustainability, 7(2): 1558-1575.

ZENG, X., HU, T., GUO, X. and LI, X. 2014. Water transfer triggering mechanism for multi-reservoir operation in inter-basin water transfer-supply project. Water Resources Management, 28(5): 12931308.

Contact information

Mohammad Hussein Karim: Karimsistani482@gmail.com

Mahmood Mohammadghasemi: M.Mghasemi@areeo.ac.ir 